\title{
DAMPAK PUTUSAN MAHKAMAH AGUNG NOMOR 70 P/HUM/2013 TERHADAP PETANI TEBU
}

\author{
Aji Mahendra Darmawan ${ }^{1)}$, Wahyu Widodo Rodhiyawan ${ }^{2)}$ \\ 1) ajimahendradarmawan@gmail.com, Politeknik Keuangan Negara STAN \\ 2) Rdw.wahyu@gmail.com* \\ *email korespondensi
}

\begin{abstract}
The purpose of the study is to explain the effectiveness of the revocation of the Value Added Tax (VAT) exemption on certain taxable goods of a strategic nature, its implications for sugarcane farmers, and solutions for sugarcane farmers. The research method used is a literature study. The results showed that for agricultural products such as sugar cane, the most influential factors on the Supreme Court's decision Number 70 of 2013 were the business processes that apply to sugarcane farming and government policies. The business process that applies to sugarcane farming is the auction system. Meanwhile, government policies that affect sugarcane farming are the lowest retail price and the highest retail price. When agricultural products are still included in certain strategic taxable goods that are exempt from the imposition of VAT, the delivery of sugarcane agricultural products is exempted from VAT. However, when agricultural products are withdrawn from certain taxable goods, they are strategic in nature and are exempted from the imposition of VAT so that they become VAT payable without any facilities. The impact is that farmers have to charge VAT as a component of sugar COGS. Meanwhile, the profit margin cannot be changed because it is constrained by the Highest Retail Price set by the government.
\end{abstract}

Keywords: Agriculture, Sugarcane, Value added tax, VAT exemption

\begin{abstract}
Abstrak
Tujuan penelitian adalah untuk menjelaskan efektifitas pencabutan fasilitas Pajak Pertambahan Nilai (PPN) dibebaskan atas barang kena pajak tertentu bersifat strategis, implikasinya terhadap petani tebu, dan solusi bagi petani tebu. Metode penelitian yang digunakan adalah studi literatur. Hasil penelitian menunjukkan bahwa Untuk barang hasil pertanian seperti tebu, faktor yang paling berpengaruh terhadap putusan MA Nomor 70 Tahun 2013 adalah proses bisnis yang berlaku pada pertanian tebu dan kebijakan pemerintah. Proses bisnis yang berlaku pada pertanian tebu adalah sistem lelang. Sedangkan kebijakan pemerintah yang berpengaruh terhadap pertanian tebu adalah Harga Eceran Terendah dan Harga Eceran Tertinggi. Saat barang hasil pertanian masih termasuk dalam BKP tertentu bersifat strategis yang dibebaskan dari pengenaan PPN, atas penyerahan produk hasil pertanian tebu PPN dibebaskan. Akan tetapi, ketika barang hasil pertanian dicabut dari BKP tertentu bersifat trategis yang dibebaskan dari pengenaan PPN sehingga menjadi terutang PPN tanpa fasilitas. Dampak yang ditimbulkan, petani harus membebankan PPN sebagai komponen HPP gula. Sedangkan margin keuntungan tidak dapat diubah karena terkendala oleh Harga Eceran Tertinggi yang ditetapkan oleh pemerintah.
\end{abstract}

Kata kunci: Pajak pertambahan nilai, Pertanian, PPN dibebaskan, Tebu

\section{PENDAHULUAN}

Sebelum Putusan Mahkamah Agung Nomor 70 Tahun 2013 terbit, atas penyerahan barang hasil pertanian termasuk dalam Barang Kena Pajak (BKP) Tertentu bersifat strategis yang dibebaskan dari pengenaan Pajak Pertambahan Nilai (PPN). Tujuan dari pemberian fasilitas PPN pada hakikatnya untuk memberikan fasilitas perpajakan yang benar-benar diperlukan terutama untuk berhasilnya sektor kegiatan ekonomi yang berprioritas tinggi dalam skala nasional, mendorong perkembangan dunia usaha dan meningkatkan daya saing, mendukung pertahanan nasional, serta memperlancar pembangunan nasional. Pajak Masukan (PM) yang diperoleh baik melalui kegiatan operasi maupun produksi atas penyerahan BKP Tertentu bersifat strategis yang dibebaskan dari pengenaan PPN tidak dapat dikreditkan sehingga dibebankan sebagai komponen Harga Pokok Produksi. Hal demikian mengakibatkan harga jual barang menjadi lebih tinggi yang akibatnya pengusaha merasa dirugikan.

Pada akhirnya, pengusaha-pengusaha yang tergabung dalam Kamar Dagang dan Industri Indonesia (KADIN) selaku penggugat melakukan permohonan uji materiil ke Mahkamah Agung terkait barang hasil pertanian yang diatur dalam Peraturan Pemerintah 
Nomor 31 Tahun 2007 tentang Barang Kena Pajak Tertentu bersifat strategis yang dibebaskan dari pengenaan Pajak Pertambahan Nilai. Atas uji materiil yang diajukan pengusaha-pengusaha melalui KADIN, pada tanggal 25 Februari 2014 telah diterbitkan Putusan Mahkamah Agung Republik Indonesia Nomor 70 Tahun 2013. Dalam amar putusannya, Mahkamah Agung kemudian mengabulkan uji materi yang diajukan oleh KADIN dengan pertimbangan utama bahwa pengklasifikasian barang pertanian sebagai barang strategis yang memperoleh pembebasan sifatnya adalah cacat hukum. Pasal terkait pembebasan PPN hasil pertanian dalam Peraturan Pemerintah Nomor 31 Tahun 2007 dianggap bertentangan dengan Undang-Undang PPN. Dengan adanya putusan tersebut, pencabutan barang hasil pertanian dari BKP Tertentu yang bersifat strategis tentu mengakibatkan dampak secara global termasuk pertanian tebu. Atas penyerahan tebu menjadi terutang PPN dan PM yang selama ini dibayar pengusaha untuk kegiatan operasi maupun produksi menjadi dapat dikreditkan. Selain itu juga dapat mengurangi harga jual produk hasil pertanian tebu dengan cara mengeluarkan unsur PM yang selama ini dibebankan pada unsur HPP.

Pemberlakuan putusan Mahkamah Agung Nomor 70 Tahun 2013 juga berdampak pada pihak selain pengusaha. Dampak yang timbul atas putusan ini adalah potensi ketidakadilan berupa beban administrasi yang tinggi pada golongan petani dan kelompok tani. Kondisi ini sekaligus memberikan gambaran bahwa terdapat kesenjangan hukum dan konflik kepentingan antara KADIN dan petani dalam penerbitan Putusan Mahkamah Agung Nomor 70 Tahun 2013.

Gambaran terkait tebu di Indonesia adalah luas panen tebu mengalami peningkatan sejak tahun 1980. Pada tahun 1980, luas panen tebu di Indonesia hanya seluas 316.063 ha. Luas ini kemudian meningkat sebesar 50,96\% menjadi 477.123 ha pada tahun 2013 dan diperkirakan akan kembali meningkat menjadi sebesar 472.693 ha di tahun 2016. Peningkatan luas panen ini disebabkan oleh adanya peningkatan pada luas panen tebu di Perkebunan Rakyat. Hal ini dikarenakan sebagian besar perkebunan tebu di Indonesia diusahakan oleh petani tebu rakyat.

Tabel 1 Rata-Rata Pertumbuhan dan Kontribusi Luas Panen Tebu di Indonesia Menurut Jenis Pengusahaan, 1980-2013.

\begin{tabular}{|l|c|c|c|c|}
\hline \multirow{2}{*}{ Tahun } & \multicolumn{4}{|c|}{ Luas Panen (Ha) } \\
\cline { 2 - 5 } & $\begin{array}{c}\text { Perkebunan } \\
\text { Rakyat }\end{array}$ & $\begin{array}{c}\text { Perkebunan Besar } \\
\text { Negara }\end{array}$ & $\begin{array}{c}\text { Perkebunan Besar } \\
\text { Swasta }\end{array}$ & INDONESIA \\
\hline \multicolumn{2}{|c|}{ Rata-rata pertumbuhan(\%) } & & & \\
\hline $1980-2013^{*}$ & 1,77 & 1,73 & 5,46 & 1,06 \\
\hline $1980-1997$ & 1.64 & 3,11 & 8,29 & 0,87 \\
\hline $1998-2013^{*}$ & 1.92 & 0,18 & 2,29 & 1,28 \\
\hline Rata-rata kontribusi(\%) & & & 100,00 \\
\hline $1980-2013^{*}$ & 63,50 & 20,73 & 15,77 & 100,00 \\
\hline $1980-1997$ & 70,55 & 21,04 & 8,42 & 100,00 \\
\hline $1998-2013^{*}$ & 55,57 & 20,39 & 24,04 & \\
\hline
\end{tabular}

Sumber: Direktorat Jenderal Perkebunan dalam buku "Outlook Komoditi Tebu"

Dalam tabel 1 disajikan rata-rata pertumbuhan dan rata-rata kontribusi untuk jenis pengusahaan tebu pada periode tahun 1980-2013, 1980-1997 dan 1998-2013. Periode 19802013, rata-rata sebanyak 63,5\% luas panen perkebunan tebu di Indonesia diusahakan oleh sektor Perkebunan Rakyat. Meskipun luas panen mengalami peningkatan, laju pertumbuhan luas panen tebu di Indonesia dalam periode tahun 1980-2013 tidak terlalu tinggi. Dari Tabel II.1 dapat dilihat bahwa secara rata-rata, pertumbuhan luas panen tebu Indonesia sejak 1980 hingga 2013 hanya mencapai 1,06\% per-tahun atau 4.547 ha per-tahunnya. Data perkembangan luas panen tebu dapat dilihat pada Lampiran 1. Dengan kontribusi luas panen diatas, perkebunan tebu rakyat rata-rata mampu menyumbang 63,9\% produksi tebu Indonesia setiap tahunnya. Produksi tebu dalam hal ini dalam wujud gula hablur. 
Journal of Law, Administration, and Social Science

Volume 1 No. 1, Juni 2021

Tabel 2 Rata-Rata Pertumbuhan Dan Kontribusi Produksi Tebu di Indonesia Menurut Jenis Pengusahaan, 1980-2013.

\begin{tabular}{|c|c|c|c|c|}
\hline \multirow[b]{2}{*}{ Tahun } & \multicolumn{4}{|c|}{ Produksi (Ha) } \\
\hline & $\begin{array}{c}\text { Perkebunan } \\
\text { Rakyat }\end{array}$ & $\begin{array}{l}\text { Perkebunan } \\
\text { Besar Negara }\end{array}$ & $\begin{array}{l}\text { Perkebunan } \\
\text { Besar Swasta }\end{array}$ & INDONESIA \\
\hline \multicolumn{5}{|c|}{ Rata-rata pertumbuhan(\%) } \\
\hline $1980-2013 *$ & 3,34 & 1,38 & 10,75 & 2,94 \\
\hline 1980-1997 & 3,80 & 2,38 & 17,71 & 3,86 \\
\hline 1998-2013* & 2,82 & 0,25 & 2,93 & 1,91 \\
\hline \multicolumn{5}{|c|}{ Rata-rata kontribusi $(\%)$} \\
\hline $1980-2013 *$ & 63,90 & 16,88 & 19,22 & 100,00 \\
\hline $1980-1997$ & 73,62 & 17,33 & 9,05 & 100,00 \\
\hline 1998-2013* & 52,96 & 16,39 & 30,66 & 100,00 \\
\hline
\end{tabular}

Sumber: Direktorat Jenderal Perkebunan dalam buku "Outlook Komoditi Tebu"

Rata-rata pertumbuhan produksi tebu adalah 2,94\% per-tahun atau 39.122 ton per tahun sedangkan untuk rata-rata pertumbuhan produksi perkembunan rakyat sebesar 3,34\%. Sama halnya dengan luas panen dan produksi tebu, produktivitas tebu Indonesia berkecenderungan meningkat dalam periode 1980-2013. Produktivitas tebu tahun 1980 tercatat mencapai 3,99 ton/ha yang kemudian meningkat hingga 37,29\% di tahun 2013 dengan produktivitas mencapai 5,47 ton/ha. Secara rata-rata pertumbuhan produktivitas tebu Indonesia mencapai $2,16 \%$ pertahun.

Berdasarkan Lampiran Peraturan Pemerintah Nomor 31 Tahun 2007, dijelaskan bahwa tebu (batang) yang ditebang/dipotong merupakan barang hasil pertanian yang bersifat strategis yang atas impor dan/atau penyerahannya dibebaskan dari pengenaan Pajak Pertambahan Nilai. Setelah terbit putusan Mahkamah Agung Nomor 70 Tahun 2013, dirjen pajak menerbitkan SE24/PJ/2014 yang salah satu isinya menyebutkan bahwa Barang hasil pertanian yang merupakan hasil perkebunan, tanaman hias dan obat, tanaman pangan, dan hasil hutan sebagaimana ditetapkan dalam Lampiran Peraturan Pemerintah Nomor 31 Tahun 2007 yang semula dibebaskan dari pengenaan PPN berubah menjadi dikenakan PPN sehingga atas penyerahan dan impornya dikenai PPN dengan tarif $10 \%$, sedangkan atas ekspornya dikenai PPN dengan tarif $0 \%$.

Konsekuensi hukum yang timbul adalah atas penyerahan produk hasil pertanian tebu menjadi terutang PPN dan pengusaha produk pertanian tebu wajib melaporkan usahanya untuk dikukuhkan sebagai Pengusaha Kena Pajak, apabila sampai dengan suatu bulan dalam tahun buku jumlah peredaran bruto dan/atau penerimaan brutonya melebihi Rp4.800.000.000,00 (empat miliar delapan ratus juta rupiah).

Penelitian terdahulu dilakukan oleh Wulandari (2015) yang menjelaskan akuntansi pajak pertambahan nilai pada pabrik gula. Sedangkan Fauziyah (2018) meneliti pajak pertambahan nilai pada industri gula. Lain halnya dengan Utami (2018) menjelaskan pajak pertambahan nilai terhadap tetes tebu (molases). Hal berbeda juga dilakukan oleh Rachman (2008) yang meneliti pajak pertambahan nilai atas jasa penggilingan tebu. Berbagai penelitian terdahulu tersebut tentunya sangat berbeda dengan penelitian yang dilakukan yang membahas pajak pertambahan nilai terhadap perubahan fasilitas perpajakan. Tujuan penelitian adalah untuk menjelaskan efektifitas pencabutan fasilitas Pajak Pertambahan Nilai (PPN) dibebaskan atas barang kena pajak tertentu bersifat strategis, implikasinya terhadap petani tebu, dan solusi bagi petani tebu. 


\section{KAJIAN PUSTAKA}

English (dalam Wijaya \& Sabina, 2021) mendefinisikan PPN sebagai pajak universal atas kegiatan konsumsi, yang merupakan pajak tidak langsung yang dibebankan oleh tiap konsumen atas transaksi barang kena pajak ataupun jasa kena pajak tertentu. PPN bersifat pajak tidak langsung, yang berarti PPN dibayarkan kepada kas negara oleh penjual yang berasal dari uang yang dipungut dari pembeli, namun pembeli juga dapat menyetorkan sendiri PPN ke kas negara jika undang-undang menyatakan demikian (Arkhan \& Rodhiyawan, 2021). Adapun Thuronyi (2003, dalam Azizah \& Wijaya, 2020) menjelaskan PPN adalah pajak transaksi yang dipungut pada semua tahap produksi dan distribusi. Pajak ini dikenakan atas transaksi barang dan jasa. Transaksi yang dikenakan pajak adalah pengadaan barang dan jasa yang diatur dalam peraturan perundang-undangan. Barang yang dimaksud adalah barang berwujud, kecuali tanah dan uang. Sedangkan jasa yang dikenakan PPN tidak dapat ditentukan secara pasti dan menyeluruh. Pajak pertambahan nilai menurut Pohan (2016, dalam Wijaya \& Nirvana, 2021) pada hakikatnya merupakan beban konsumen akhir karena mengonsumsi barang atau jasa yang menjadi objek pajak, yang tanggung jawabnya digeser ke pihak lain, dalam hal ini pengusaha kena pajak.

\section{Proses Bisnis Pertanian Tebu}

Pada dasarnya, penjualan gula dilaksanakan kepada penyalur/pembeli yang berminat untuk memperoleh harga jual yang terbaik yang menguntungkan produsen. Beberapa alternatif penjualan gula, yaitu sistem lelang, sistem bid offer, sistem penjualan bebas, sistem penjualan langsung kepada konsumen, sistem penjualan dengan uang muka, dilaksanakan pada kondisi tertentu seperti pada saat produsen membutuhkan dana likuid, dan kerjasama keagenan pemasaran dengan Bulog. Namun demikian, semenjak dikeluarkannya Kepmenperindag No 643/MPP/Kep/9/2002 yang disempurnakan dengan Kepmenperindag No 527/MPP/Kep/9/2002, maka penjualan gula PG dan petani umumnya dilakukan secara lelang. Hal ini didukung oleh SOP penjualan harga yang dikeluarkan oleh PTPN IX.

Proses bisnis dalam usaha pertanian tebu tidak terlepas dari proses lelang gula. Proses lelang gula diikuti oleh beberapa pelaku diantaranya Petani, PTPN, Distributor/pedagangan besar. Tebu yang dihasilkan oleh petani disuplai ke PTPN untuk kemudian diolah menjadi Gula Kristal Putih (GKP). Oleh Karena itu proses lelang hanya untuk GKP dan tidak untuk Gula Kristal Rafinasi (GKR). Gula Kristal Putih ini kemudian dalam jumlah curah dilelang dengan mengacu pada Harga Pembelian Petani (HPP) yang ditetapkan Pemerintah sehingga harga yang terbentuk dalam proses lelang akan berada pada kisaran HPP. Harga yang terbentuk terkadang berada di atas HPP, namun terkadang harga yang terbentuk justru di bawah HPP. Secara hipotesis, harga yang terbentuk dari mekanisme lelang, yang umumnya mengacu kepada HPP, merupakan harga yang layak (fair) bagi petani karena telah mempertimbangkan keuntungan bagi petani. Dengan kata lain, harga lelang selama mengacu pada HPP merupakan harga terbaik bagi petani, mengingat peran HPP sebagai acuan harga minimum di tingkat produsen. Dalam implementasinya, harga lelang merupakan harga kesepakatan yang dijadikan dasar dalam pembentukan harga berikutnya, yaitu harga di tingkat distributor dan pengecer dalam periode tertentu (umumnya per bulan). Dengan demikian, dengan mekanisme harga lelang, produsen setidaknya dapat memperoleh harga yang wajar, transparan, dan relatif stabil selama periode tertentu. Hal ini ditambah dengan besaran HPP yang cenderung stabil maka dapat dikatakan bahwa harga yang terbentuk dalam proses lelang akan menjaga tingkat stabilisasi harga di tingkat petani.

\section{Kontrol Harga}

Kegiatan ekonomi suatu negara adakalanya mengalami kegagalan pasar. Untuk mengatasi kegagalan pasar seperti kekakuan harga, monopoli, dan eksternalitas yang merugikan, maka peran pemerintah sangat diperlukan dalam perekonomian suatu negara. 
Peranan ini dapat dilakukan dalam bentuk intervensi langsung maupun tidak langsung. Salahsatu intervensi pemerintah yang dilakukan adalah melalui kebijakan penetapan harga maksimum (ceiling price) dan penetapan harga minimum (floor price) untuk melindungi konsumen maupun produsen.

Ceiling Price atau harga tertinggi adalah harga maksimum yang ditetapkan berkenaan dengan menurunnya penawaran barang di pasar. Ceiling Price efektif dalam melindungi konsumen dari gejolak harga yang tak terhingga. Pada ceiling price, harga maksimum terdapat di bawah harga keseimbangan. Dengan menurunnya harga jual, maka permintaan akan meningkat (hukum permintaan). Kondisi ini mendorong permintaan terus bertambah, sehingga jumlah barang yang diminta lebih tinggi dari barang yang ditawarkan (shortage). Hal tersebut yang akhirnya mengakibatkan kelangkaan barang. Bila sudah sampai titik shortage, maka pemerintah akan menambah jumlah penawaran barang di pasar, contohnya dengan cara pemberian subsidi, mengimpor barang, mengurangi pajak, dan lain sebagainya.

Sedangkan Floor Price atau harga dasar adalah harga eceran terendah yang ditetapkan oleh pemerintah terhadap suatu barang yang disebabkan oleh melimpahnya penawaran barang tersebut di pasar. Floor Price efektif melindungi produsen dari penurunan harga barang yang tak terhingga. Pada kondisi ini tingkat penawaran barang lebih tinggi dari permintaan (surplus). Penawaran yang lebih tinggi akan mengurangi tingkat permintaan barang. Menurunnya jumlah permintaan mengakibatkan harga barang terus merosot sampai dibawah harga keseimbangan. Bila hal tersebut terus dibiarkan maka produsen akan merugi. Oleh sebab itu, pemerintah menetapkan harga dasar, untuk mencegah harga pasar terus merosot tajam.

\section{METODE}

Penelitian menggunakan metode penelitian studi kepustakaan. Metode penelitian kepustakaana dalah metode yang dilaksanakan dengan cara mempelajari sejumlah literatur berupa kajian pustaka, buku, jurnal, berita di media masa dan lainnya untuk memperoleh dasar teoritis mengenai permasalahan yang akan dibahas dalam penelitian ini (Yudhistira, 2021).

\section{HASIL DAN PEMBAHASAN}

\section{Pencabutan Fasilitas PPN Atas Produk Hasil Pertanian Tebu}

Barang hasil pertanian termasuk dalam Barang Kena Pajak (BKP) bersifat strategis yang dibebaskan dari Pengenaan Pajak Pertambahan Nilai (PPN) berdasarkan Peraturan Pemerintah Nomor 31 Tahun 2007. Sehingga atas penyerahan BKP berupa barang hasil pertanian yang dilakukan oleh PKP menjadi terutang PPN namun Pajak Keluaran (PK) yang dipungut oleh PKP sebesar nol. Meskipun PK sebesar nol dan PKP juga memiliki Pajak Masukan (PM), pelaksanaan pemungutan PPN dengan mekanisme PK-PM (Indirect Substraction Method) tidak dapat dilaksanakan. Hal ini berkaitan dengan Pasal 16B ayat (3) UU PPN yang berbunyi "Pajak Masukan yang dibayar untuk perolehan Barang Kena Pajak dan/atau perolehan Jasa Kena Pajak yang atas penyerahannya dibebaskan dari pengenaan Pajak Pertambahan Nilai tidak dapat dikreditkan.". PM yang telah disetor ke Kas Negara (KN) yang tidak dapat dikreditkan oleh PKP kemudian dibebankan ke komponen Harga Pokok Produksi (HPP) dalam harga jual. Hal demikian membuat pengusaha merasa dirugikan karena harga jual menjadi lebih tinggi.

Pada akhirnya, pengusaha yang tergabung dalam Kamar Dagang dan Industri Indonesia (KADIN) melakukan pormohonan uji materiil ke Mahkamah Agung terkait barang hasil pertanian yang diatur dalam Peraturan Pemerintah Nomor 31 Tahun 2007 tentang Barang Kena Pajak Tertentu bersifat strategis yang dibebaskan dari pengenaan Pajak Pertambahan Nilai. Atas uji materiil yang diajukan pengusaha-pengusaha melalui KADIN, pada tanggal 25 Februari 2014 telah diterbitkan Putusan Mahkamah Agung Republik Indonesia Nomor 70 Tahun 2013. Dalam amar putusannya, Mahkamah Agung kemudian mengabulkan uji materi 
yang diajukan oleh KADIN dengan pertimbangan utama bahwa pengklasifikasian barang pertanian sebagai barang strategis yang memperoleh pembebasan sifatnya adalah cacat hukum. Pasal terkait pembebasan PPN hasil pertanian dalam Peraturan Pemerintah Nomor 31 Tahun 2007 dianggap bertentangan dengan Undang-Undang PPN. Berkaitan dengan permasalahan tersebut, Direktorat Jenderal Pajak (DJP) menerbitkan Surat Edaran Nomor 24 Tahun 2014 sebagai tindak lanjut atas instruksi dari Mahkamah Agung setelah terbitnya Putusan Mahkamah Agung Nomor 70 Tahun 2013. Dan sebagai konsekuensi hukum atas Putusan Mahkamah Agung Nomor 70 Tahun 2013, pada tahun 2015 pemerintah menerbitkan Peraturan Pemerintah Nomor 81 Tahun 2015 yang isinya mencabut Peraturan Pemerintah Nomor 31 Tahun 2007.

Terbitnya Putusan MA Nomor 70 Tahun 2013 mengakibatkan dicabutnya barang hasil pertanian dari barang strategis yang dibebaskan dari pengenaan PPN berdasarkan Peraturan Pemerintah Nomor 31 Tahun 2007. Dengan demikian, barang yang tergolong barang hasil pertanian yang semula dibebaskan dari pengenaan PPN menjadi tidak memperoleh fasilitas dibebaskan dari pengenaan PPN. Perlakuan terhadap jenis barang yang tergolong barang hasil pertanian pun berbeda-beda tergantung jenis barang masing-masing. Jenis barang hasil pertanian mempunyai konsekuensi hukum masing-masing setelah dicabutnya barang hasil pertanian dari BKP Tertentu bersifat strategis yang memperoleh fasilitas PPN dibebaskan.

Perlakuan sebagaimana dimaksud dalam SE Direktur Jenderal Pajak Nomor 24 Tahun 2014 sebagai berikut : (a) Barang hasil pertanian berupa buah-buahan dan sayur-sayuran sebagaimana ditetapkan dalam Lampiran Peraturan Pemerintah Nomor 31 Tahun 2007 termasuk barang yang tidak dikenakan PPN (Bukan Barang Kena Pajak) sesuai Pasal 4A ayat (2) huruf b Undang-Undang PPN sehingga atas penyerahan, impor, maupun ekspornya tidak dikenai PPN; (b) Barang hasil pertanian lain yang tidak ditetapkan dalam Lampiran Peraturan Pemerintah Nomor 31 Tahun 2007, yaitu beras, gabah, jagung, sagu dan kedelai adalah barang yang tidak dikenakan PPN (Bukan Barang Kena Pajak) sesuai Pasal 4A ayat (2) huruf b Undang-Undang PPN sehingga atas penyerahan, impor, maupun ekspornya tidak dikenai PPN; (c) Barang hasil pertanian yang merupakan hasil perkebunan, tanaman hias dan obat, tanaman pangan, dan hasil hutan sebagaimana ditetapkan dalam Lampiran Peraturan Pemerintah Nomor 31 Tahun 2007 yang semula dibebaskan dari pengenaan PPN berubah menjadi dikenakan PPN sehingga atas penyerahan dan impornya dikenai PPN dengan tarif $10 \%$, sedangkan atas ekspornya dikenai PPN dengan tarif 0\%; (d) Pengusaha (orang pribadi maupun badan) yang melakukan penyerahan barang hasil pertanian tersebut wajib memungut PPN dan untuk itu wajib dikukuhkan sebagai Pengusaha Kena Pajak, kecuali pengusaha yang termasuk pengusaha kecil dengan omzet sampai dengan Rp 4,8 milyar per tahun sebagaimana diatur dalam Peraturan Menteri Keuangan Nomor 197/PMK.03/2013 tentang Perubahan atas Peraturan Menteri Keuangan Nomor 68/PMK.03/2010 tentang Batasan Pengusaha Kecil Pajak Pertambahan Nilai.

Implikasi atas terbitnya SE-24/PJ/2014 secara garis besar adalah barang hasil pertanian yang semula dibebaskan dari pengenaan PPN menjadi barang yang tidak dikenai PPN atau terutang PPN. Untuk barang hasil pertanian yang tergolong ke dalam barang yang terutang PPN, pihak yang melakukan penyerahan wajib dikukuhkan sebagai PKP apabila dalam satu tahun memiliki Peredaran Bruto lebih dari 4,8 M. Jenis barang hasil pertanian yang semula dibebaskan dari pengenaan PPN namun kini menjadi terutang PPN berdasarkan SE-24/PJ/2014 adalah hasil perkebunan sebagaimana ditetapkan dalam Lampiran Peraturan Pemerintah Nomor 31 Tahun 2007. Salah satu jenis barang yang terlampir dalam Lampiran PP Nomor 31 Tahun 2007 adalah "tebu(batang) yang ditebang/dipotong". Atas penyerahan barang hasil pertanian tebu yang semula dibebaskan dari pengenaan PPN menjadi terutang PPN sebesar 10\%. Pihak yang melakukan penyerahan barang hasil pertanian tebu wajib dikukuhkan sebagai PKP apabila dalam setahun memiliki Peredaran Bruto lebih dari 4,8 M. 


\section{Dampak Pencabutan Fasilitas PPN Atas Produk Hasil Pertanian Tebu}

Terdapat dua hal yang menjadi pokok permasalahan dari terbitnya Putusan Mahkamah Agung Nomor 70 Tahun 2013 terhadap petani tebu. Pertama, perubahan perlakukan menimbulkan dampak tersendiri. Perlakuan pajak setelah barang hasil pertanian menjadi terutang PPN dibandingkan dengan saat masih dibebaskan dari pengenaan PPN memiliki perlakuan dan konsekuensi yang berbeda. Untuk memahami perbedaan ini, perlu adanya pemahaman tentang hakikat fasilitas PPN dibebaskan dalam mekanisme pemungutan PPN. Kedua, perbedaan perlakuan menimbulkan kewajiban perpajakan di bidang PPN. Mengingat karakteristik PPN sebagai pajak objektif, selama terdapat penyerahan BKP, maka terdapat kewajiban untuk memungut PPN. Hal ini berlaku pada setiap pihak yang terlibat dalam usaha pertanian tebu baik dalam Perkebunan Rakyat (PR), Perkebunan Besar Negara (PBN) maupun Perkebunan Besar Swasta (PBS).

Gambar 1 Rata-Rata Produksi Tebu Selama 1980-2013 Menurut Jenis Pengusahaan

RATA-RATA KONTRIBUSI PRODUKSI TEBU SELAMA 1980-2013 MENURUT JENIS PENGUSAHAAN.

$\square \mathrm{PR} \square \mathrm{PBN} \square \mathrm{PBS}$

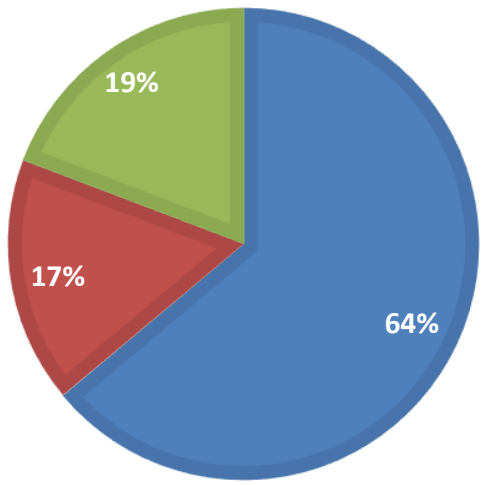

Sumber : Diolah dari buku "Outlook Komoditi Tebu"

Berdasarkan data dari Direktorat Jenderal Perkebunan dalam Buku "Outlook Komoditi Tebu", Rata-rata kontribusi produksi tebu selama 1980-2013 ditunjang oleh Perkebunan Rakyat (PR) sebesar 63,90 persen, Perkebunan Besar Negara (PBN) sebesar 16,88 persen dan Perkebunan Besar Swasta (PBS) 19,22 persen. Hal ini mengindikasikan bahwa Perkebunan Rakyat (PR) yang dikelola oleh Petani Tebu merupakan penopang produksi tebu dalam negeri. Dengan dicabutnya fasilitas PPN dibebaskan atas produk hasil pertanian tebu tentunya akan berdampak cukup besar terhadap kondisi perekonomian, mengingat Perkebunan Rakyat (PR) memiliki kontribusi yang tinggi dalam produksi tebu dalam negeri.

Dicabutnya barang hasil pertanian dari BKP Strategis yang dibebaskan dari pengenaan PPN menimbulkan barang hasil pertanian tebu menjadi terutang PPN. Oleh karena itu, petani tebu wajib dikukuhkan sebagai PKP untuk kemudian melakukan pemungutan PPN apabila dalam satu tahun memiliki Peredaran Bruto lebih dari 4,8 M. Apabila Peredaran Bruto petani tebu kurang dari 4,8 M selama setahun, maka petani tidak perlu dikukuhkan sebagai PKP dan melakukan pemungutan PPN. Namun dapat memilih untuk dikukuhkan sebagai PKP meskipun Peredaran Bruto dalam setahun kurang dari 4,8 M.

Realita yang terjadi di lapangan justru merugikan petani tebu. Petani tebu memikul beban PPN, padahal petani bukan konsumen akhir. Pada dasarnya, agar petani tidak menanggung beban PPN, petani dapat membebankan PPN yang telah dipungut ke dalam harga jual, sehingga PPN tetap menjadi beban konsumen. Akan tetapi, hal ini terkendala oleh Harga Eceran Tertinggi (HET) yang ditetapkan oleh pemerintah. Sehingga pada akhirnya, meskipun 
PPN dapat dibebankan ke dalam harga jual, petani tetap tidak dapat mematok harga melewati Harga Eceran Tertinggi (HET) yang ditetapkan pemerintah dan berimbas pada berkurangnya keuntungan yang diperoleh petani. Penyebab munculnya permasalahan ini tidak terlepas dari mekanisme penyerahan yang dilakukan oleh petani tebu ke pabrikan. Selain itu juga disebabkan karena penetapan Harga Eceran Tertinggi (HET) dan dicabutnya fasilitas PPN dibebaskan.

Untuk memahami lebih dalam mengenai dampak yang ditimbulkan dari pencabutan fasilitas PPN atas produk hasil pertanian, khususnya barang hasil pertanian tebu, maka perlu adanya pemahaman terhadap faktor-faktor yang terlibat dalam timbulnya permasalahan. Oleh karena itu, perlu adanya pemahaman mengenai hakikat fasilitas PPN dibebaskan, penetapan Harga Eceran Tertinggi (HET) serta mekanisme penyerahan yang dilakukan petani tebu ke pabrikan. Mekanisme penyerahan yang dilakukan oleh petani ke pabrikan tidak terlepas dari proses bisnis yang terjadi di pertanian tebu. Penjualan produk hasil pertanian tebu yang diserahkan oleh petani tebu dijual dalam bentuk gula yang dilaksanakan secara lelang.

\section{Gambar 2 Alur Proses Bisnis Pertanian Tebu.}

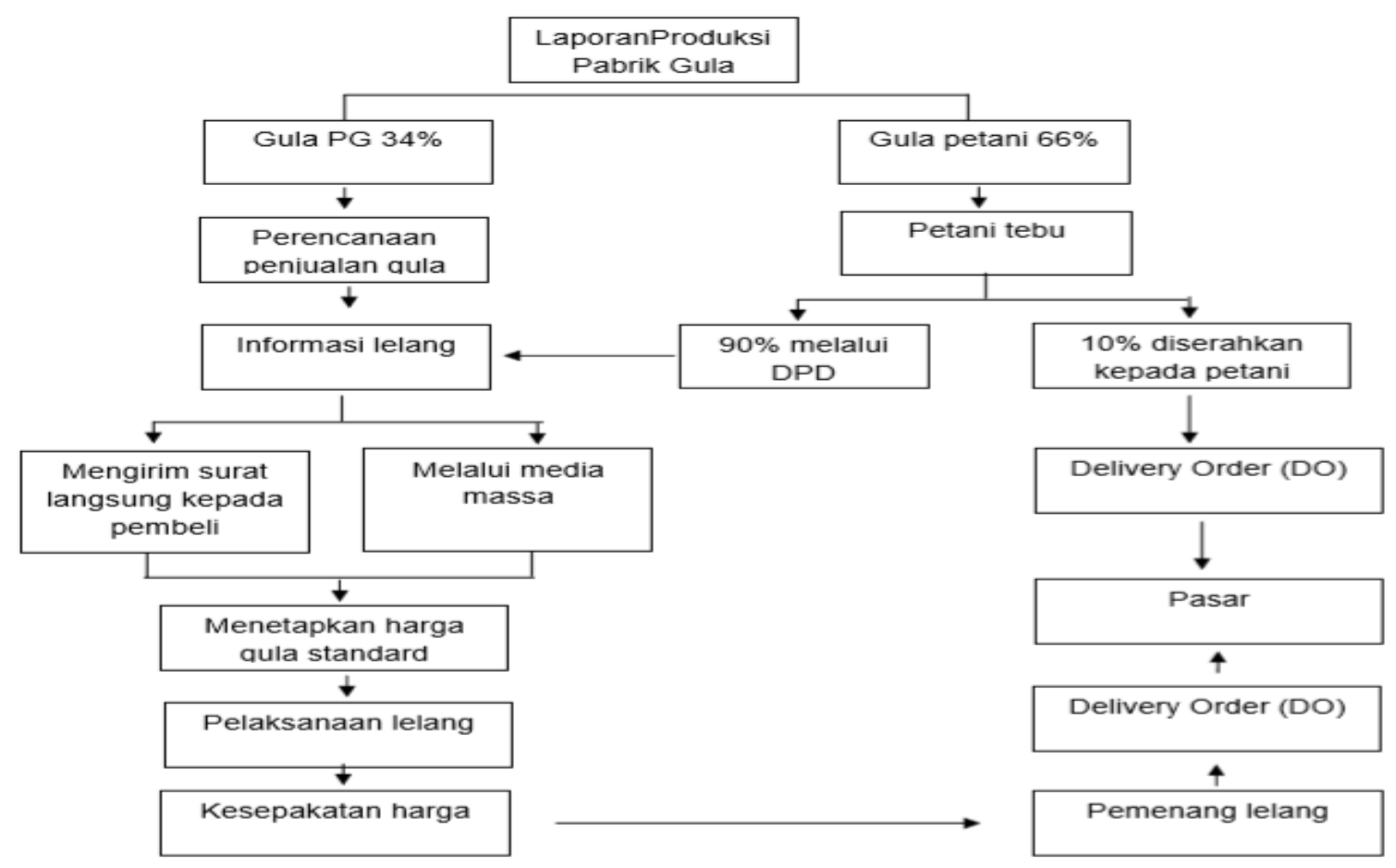

Sumber : Analisis Lelang Gula PTPN/Petani Dalam Rangka Stabilisasi Harga

Mekanisme penjualan gula didasarkan pada bagi hasil gula milik PG dengan petani dimana PG mendapatkan 34\% sementara petani $66 \%$. Setelah bagi hasil dilakukan, PG membuat perencanaan penjualan gula yang umumnya meliputi jumlah gula yang akan dijual, tempat dan waktu pelaksanaan lelang. Jika petani ikut serta dalam proses lelang, maka penjualan gula petani akan dikoordinir oleh asosiasi dengan kuantitas mencapai $90 \%$ dari gula milik petani. Dalam hal ini, petani dapat menjual $10 \%$ gulanya secara mandiri. Pada proses selanjutnya, PG akan menghubungi pembeli potensial sebagai peserta lelang, baik secara langsung atau melalui media umum. Sebagai tahap awal sebelum proses lelang, beberapa hal yang dilakukan antara lain pembentukan panitia lelang, pengumuman harga acuan (standard) yang biasanya mengacu pada Harga Patokan Petani (HPP) yang ditetapkan pemerintah, dan sejumlah aturan lelang yang bersifat teknis. Pelaksanaan lelang diharapkan bersifat transparan dan memberikan posisi tawar yang sejajar antara penjual dan pembeli. Dengan demikian, setelah tercapai kesepakatan harga, panitia lelang akan mengumumkan pemenang lelang dan dilakukan penerbitan Delivery Order (DO) sebagai bukti kesepakatan jumlah dan harga gula. 
Jika dicermati lebih lanjut, mekanisme penyerahan antara petani tebu dan pabrikan ternyata penyerahan tebu oleh petani dibayar dalam bentuk gula, bukan dalam bentuk uang tunai.

Gambar 2 Mekanisme Penyerahan Antara Petani Tebu dan Pabrikan

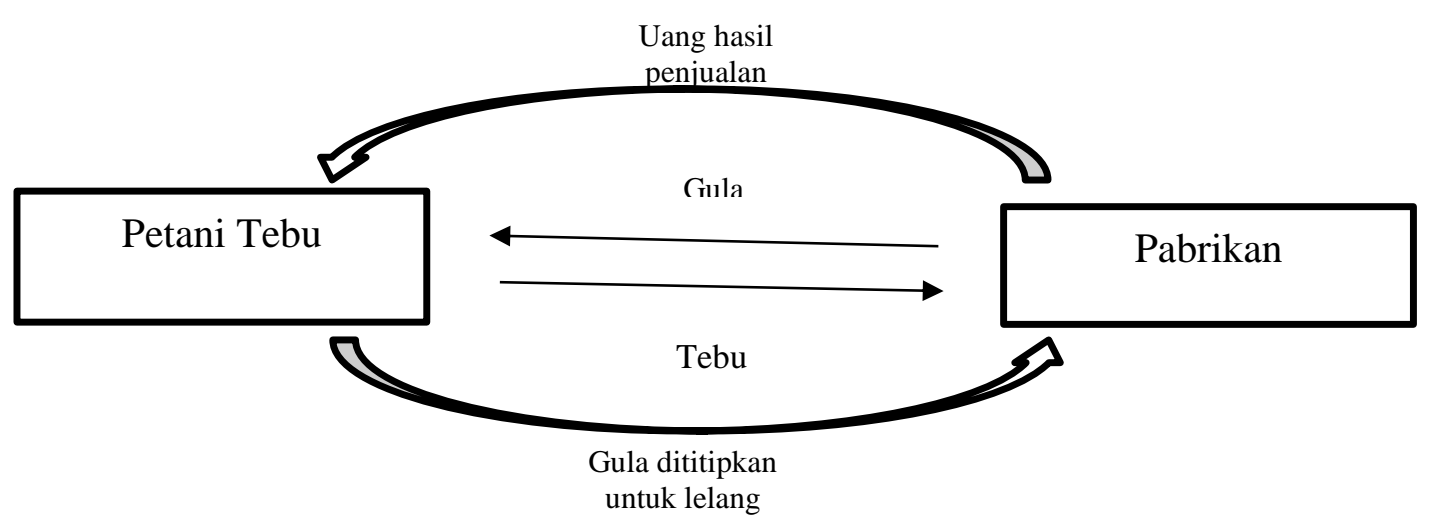

Transaksi di atas dapat disebut dengan transaksi tukar-menukar. Sesuai UU PPN, transaksi di atas termasuk penyerahan yang terutang PPN. Meskipun transaksi di atas tegolong trasaksi yang terutang PPN, tetapi tetap harus memperhatikan apakah petani mempunyai omset lebih dari 4,8 M tiap tahun. Karena perlakuan yang terjadi atas transaksi seperti pada gambar di atas akan berbeda tergantung pada petani tebu merupakan PKP/non-PKP maupun apabila petani tebu memilih untuk dikukuhkan sebagai PKP meskipun omset dalam setahun tidak lebih dari 4,8 M.

\section{Transaksi apabila pabrikan dan petani tebu sama-sama PKP}

Penyerahan tebu oleh petani maupun penyerahan gula oleh pabrikan terutang PPN dan wajib dipungut PPN. Misalkan petani tebu menyerahkan 250 ton tebu senilai 200 juta kepada pabrikan gula (wajib dipungut PPN). Seminggu kemudian pabrikan menyerahkan 25 ton gula senilai 250 juta kepada petani tebu (wajib dipungut PPN). Gula kemudian dititipkan kepada pabrikan untuk dijual kepada pihak lain. Sebulan kemudian gula terjual (wajib dipungut PPN) dan pabrikan menyerahkan uang hasil penjualan sebesar 250 juta kepada petani. Misalkan untuk melakukan penyerahan 250 ton tebu petani mengeluarkan biaya-biaya sebesar 20 juta. Pengeluaran sebesar 10 juta merupakan pengeluaran yang memiliki Faktur Pajak PPN.

Dari ilustrasi di atas, petani tebu mempunyai PK sebesar 45 juta. Terdiri dari PK atas penyerahan tebu ke pabrikan sebesar 20 juta dan 25 juta atas penyerahan gula yang dijual oleh pabrikan. Petani tebu juga mempunyai PM sebesar 26 juta. Terdiri dari penyerahan atas gula yang diterima dari pabrikan sebesar 25 juta dan PM atas pengeluaran yang memiliki Faktur Pajak PPN sebesar 1 juta. Dengan demikian, PPN terutang sebesar 19 juta (45 juta-26 juta). PPN ini ditanggung oleh pembeli gula, bukan menjadi tanggungan petani. Sehingga laba sebelum PPh petani adalah 250 juta dikurangi 20 juta (biaya-biaya yang dikeluarkan) sebesar 230 juta.

\section{Transaksi apabila petani tebu bukan PKP}

Penyerahan tebu oleh petani tidak dikenai PPN sedangkan penyerahan gula oleh pabrikan wajib dipungut PPN. Misalkan petani menyerahkan 250 ton tebu senilai 200 juta ke pabrikan gula (tidak dipungut PPN). Seminggu kemudian pabrikan menyerahkan 25 ton gula senilai 250 juta ke petani tebu (wajib dipungut PPN). Gula ini dititipkan ke pabrikan untuk dijual kepada pihak lain. Sebulan kemudian gula terjual (tidak dipungut PPN). Dan pabrikan menyerahkan uang hasil penjualan sebesar 275 juta $(250$ juta +25 juta mark up PPN). Misalkan untuk melakukan penyerahan 250 ton tebu petani mengeluarkan biaya-biaya sebesar 20 juta. Pengeluaran sebesar 10 juta merupakan pengeluaran yang memiliki Faktur Pajak PPN. Faktur 
Pajak Masukan yang diterima petani tebu atas transaksi di atas adalah 20 juta atas gula tebu yang diterima dan 1 juta atas biaya-biaya (seluruhnya tidak bisa dikreditkan sehingga menjadi biaya). Sehingga laba bersih sebelum $\mathrm{PPh}$ petani tebu sebesar 229 juta (275 juta -25 juta -20 juta -1 juta).

Dari kedua ilustrasi di atas, terlihat bahwa laba petani akan lebih besar jika menjadi PKP dibanding tidak menjadi PKP. Hal ini berkaitan dengan Pajak Masukan yang dapat dikreditkan apabila petani menjadi PKP, sehingga beban PPN dalam unsur biaya dapat dikeluarkan. Sekilas hanya permasalahan dapat atau tidaknya PM dikreditkan. Yang mana menjadi PKP lebih menguntungkan, padahal ada masalah yang lebih kompleks. Baik petani menjadi PKP atau tidak, keduanya akan bermuara pada petani menanggung beban PPN. Hal ini dikarenakan ada friksi antara PPN dan aturan pemerintah terkait Harga Eceran Tertinggi (HET). Apabila petani merupakan PKP, petani wajib memungut PPN. Di lain sisi, harga jual petani tidak boleh melewati Harga Eceran Tertinggi (HET) yang ditetapkan oleh pemerintah. Apabila harga jual gula petani ditambah PPN masih dibawah Harga Eceran Tertinggi tidak akan menjadi masalah. Yang menjadi masalah adalah apabila harga jual ditambah PPN menjadi lebih tinggi dari PPN. Apabila petani bukan PKP, petani tidak wajib memungut PPN. Pada teorinya PPN akan dibebankan dalam harga jual dengan cara di-mark-up, tetapi pada kenyataannya hal ini juga terhalang oleh Harga Eceran Tertinggi (HET) yang ditetapkan pemerintah.

Dari dua kemungkinan tersebut, masalah paling realistis terjadi di lapangan adalah mark-up PPN terhalang oleh Harga Eceran Tertinggi (HET) yang ditetapkan oleh pemerintah. Karena kebanyakan petani tebu bukan merupakan PKP. Dalam penetapan Harga Eceran Tertinggi (HET), Kementerian Perindustrian dan Perdagangan (Kemerindag) menetapkan Harga Eceran Tertinggi (HET) untuk komoditas gula sebesar 12.500 sejak 10 April 2017. Berdasarkan MOU antara Asosiasi Pengusaha Ritel Indonesia (Aprindo) dengan distributor gula yang difasilitasi oleh Kemerindag ditetapkan bahwa HET gula pasir 12.500/kg dan harga jual dari produsen 11.900/kg franco DC dengan kemasan $1 \mathrm{~kg}$ atau 10.900/kg loco pabrik yang dikemas ukuran $50 \mathrm{~kg}$ untuk dikemas ulang dalam kemasan $1 \mathrm{~kg}$ oleh retail. Jika kita bandingkan mekanisme PPN petani tebu yang berlaku dan penetapan Harga Eceran Tertinggi (HET) yang ditetapkan oleh pemerintah, kita dapat membuat ilustrasi bagaimana dampak yang dihadapi oleh petani tebu.

Gambar 3 Friksi antara Pajak Pertambahan Nilai dan Harga Eceran Tertinggi.

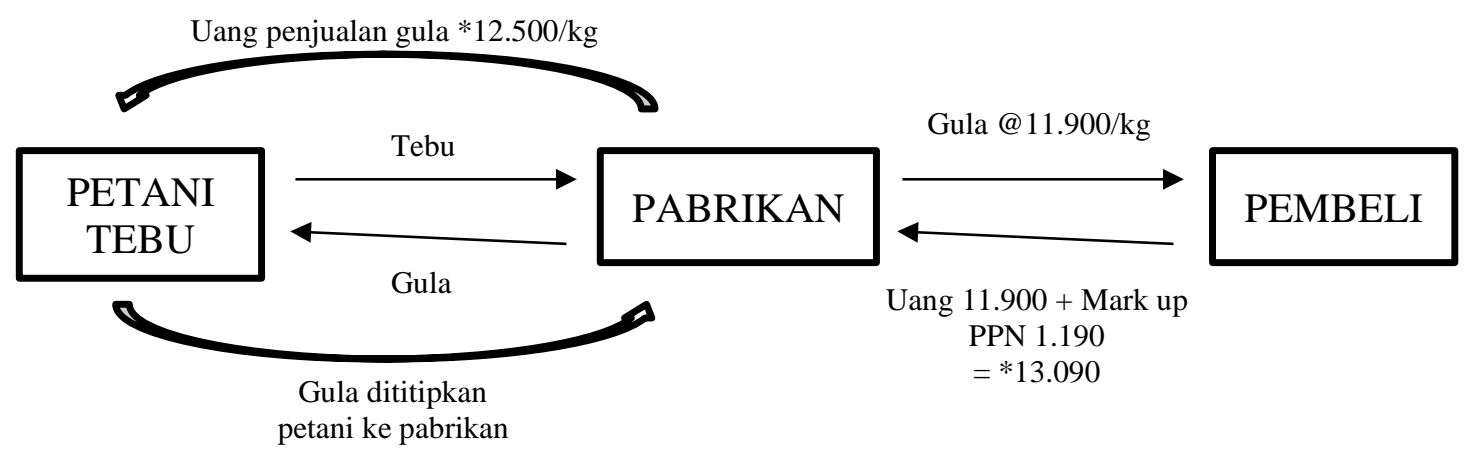

Sesuai dengan proses bisnis pertanian tebu, gula yang diterima oleh petani tebu dari pabrikan dititipkan kembali ke pabrikan untuk dilelang. Oleh pabrikan, gula dijual dengan harga $11.900 / \mathrm{kg}$. Transaksi ini terutang PPN, karena petani tebu bukan PKP, maka PPN dimark-up ke dalam harga jual. Sehingga harga jual menjadi 13.090/kg (11.900+1190). Di lain hal, Harga Eceran Tertinggi (HET) yang ditetapkan oleh pemerintah sebesar $12.500 / \mathrm{kg}$. Sehingga harga maksimal yang dapat dipatok oleh petani adalah $12.500 / \mathrm{kg}$. Ada selisih antara harga jual 13.090/kg dan HET 12.500/kg sebesar 590/kg. Hal inilah yang dianggap merugikan para petani. Petani menjadi memanggung beban PPN meskipun bukan konsumen akhir. Angka 
590/kg merupakan angka yang cukup materiil. Anggap saja terdapat penyerahan gula senilai 20 ton. Jika beban PPN yang ditanggung petani sebesar 590/kg, maka beban yang ditanggung petani menjadi 11.800 .000 rupiah.

\section{Transaksi apabila petani tebu memilih untuk dikukuhkan sebagai PKP}

Pokok permasalahan terkait beban PPN yang ditanggung petani terjadi apabila petani bukan merupakan PKP. Karena skema PK-PM tidak dapat dilakukan, petani melakukan markup PPN untuk kemudian dibebankan ke HPP. Sebenarnya hal ini tidak menjadi masalah apabila tidak ada HET. Akan tetapi, karena adanya HET, otomatis tidak seluruhnya PPN dapat dibebankan ke HPP. Masih ada sebagian yang mau tidak mau harus ditanggung petani sebesar 590/kg seperti ilustrasi di atas. Untuk mengatasi permasalahan tersebut, solusi yang dapat dilakukan adalah dengan cara mengukuhkan petani tebu menjadi PKP agar dapat menjalankan skema pemungutan PPN. Apabila petani tebu memiliki omset kurang dari 4,8 M dalam setahun, petani dapat meminta untuk dikukuhkan sebagai PKP. Kemudian mengajukan permohonan untuk menjalankan skema Pedoman Penghitungan Pengkreditan Pajak Masukan (P4PM) dalam menghitung besarnya PM. Untuk P4PM atas penyerahan BKP dikenai PPN dengan DPP sebesar 70\% dari penyerahan yang terutang PPN. Skema P4PM dapat mengurangi beban PPN yang ditanggung petani meskipun tidak sepenuhnya. Jika sebelumnya menanggung PPN 100\% (apabila tidak di mark-up). Dengan dikukuhkan sebagai PKP, petani dapat melakukan skema PK-PM. Sehingga petani mendapatkan manfaat sebesar 7\%. Beban PPN menjadi hanya 3\%.

Pabrikan merupakan PKP dan petani tebu memilih untuk dikukuhkan sebagai PKP meskipun omset setahun kurang dari 4,8 M. Penyerahan tebu oleh petani maupun penyerahan gula oleh pabrikan terutang PPN dan wajib dipungut PPN. Petani tebu menyerahkan 100 ton tebu senilai 100.000.000 kepada pabrikan gula (wajib dipungut PPN sebesar 10.000.000). Seminggu kemudian pabrikan menyerahkan 25 ton gula senilai 297.500.000 (harga gula $11.900 / \mathrm{kg}$ ) kepada petani tebu (wajib dipungut PPN sebesar 29.750.000). Gula kemudian dititipkan kepada pabrikan untuk dijual kepada pihak lain. Sebulan kemudian gula sebesar 25 ton dengan harga 11.900/kg terjual (wajib dipungut PPN). Harga termasuk mark-up PPN atas penjualan gula menjadi sebesar $13.090 / \mathrm{kg}$. Sedangkan HET yang ditetapkan oleh pemerintah sebesar $12.500 / \mathrm{kg}$. Sehingga harga maksimum yang dapat dipatok oleh pabrikan atas gula tebu adalah 12.500/kg termasuk PPN. Sehingga uang yang diperoleh petani tebu sebesar 312.500.000. Apabila unsur PPN dipisahkan dengan harga jual, terdapat PK sebesar 28.409.090. Dan harga jual oleh petani tebu atas 25 ton gula senilai 284.090.909. Sedangkan apabila tidak terpengaruh HET, hasil penjualan petani tebu seharusnya sebesar 327.250.000 terdiri dari harga jual 297.500.000 dan PPN sebesar 29.750.000. Ada selisih sebesar 13.409.090 yang dianggap merugikan petani. Sedangkan dari unsur PPN yang diterima negara sebesar 29.750.000. yang mana sebesar 13.409.090 menjadi beban petani tebu.

Selain itu, dapat dipahami apabila petani tebu memilih untuk dikukuhkan sebagai PKP dan menggunakan skema P4PM, petani tebu mempunyai PK sebesar 38.409.090. Terdiri dari PK atas penyerahan tebu ke pabrikan sebesar 10.000.000 dan 28.409.090 atas penyerahan gula yang dijual oleh pabrikan. Berdasarkan skema P4PM petani tebu mempunyai PM sebesar 26.886.363. Sehingga PK-PM sebesar 1.542.727 harus disetor ke KN. Dengan demikian, beban PPN yang ditanggung petani tebu menjadi lebih kecil. Selain itu, PPN yang diperoleh negara juga menjadi lebih besar sebesar 38.409.090.

Dari ilustrasi di atas, dapat ditarik kesimpulan bahwa beban PPN yang terpaksa ditanggung petani baik PKP maupun bukan PKP sebesar 13.409.090. Apabila petani ingin menaggung beban PPN lebih kecil dari itu, petani dapat dikukuhkan sebagai PKP kemudian melakukan skema P4PM dengan asumsi, nilai penyerahan atas barang hasil pertanian tebu ke pabrikan kurang dari 162.878.767. Angka ini merupakan perkiraan penyerahan yang akan menghasilkan pajak KB sebesar 13.409.090 apabila menggunakan skema P4PM. Jika petani 
tebu memilih dikukuhkan sebagai PKP. Selain PPN yang diperoleh oleh negara menjadi lebih besar dan beban PPN yang ditanggung petani tebu menjadi lebih kecil. Ada manfaat lain yang dapat diperoleh Direktorat Jenderal Pajak (DJP). Hal ini berkaitan dengan data dan informasi perpajakan. Karena petani tebu menjadi PKP, tentunya menerbitkan Faktur Pajak. Melalui Faktur Pajak dapat diketahui besarnya peredaran bruto dalam setahun. Dengan demikian dapat mempermudah DJP dalam melakukan penggalian potensi dan pengawasan. Melalui peredaran bruto, DJP dapat memperoleh potensi pajak Penghasilan Orang Pribadi atau Badan.

\section{PENUTUP}

\section{Simpulan}

Terbitnya putusan MA Nomor 70 Tahun 2013 mempunyai dampak yang global. Hal ini tidak terlepas dari dicabutnya barang hasil pertanian dari BKP tertentu bersifat strategis yang dibebaskan dari pengenaan PPN. Barang hasil pertanian merupakan kelompok barang yang beraneka ragam. Oleh karena itu, dampak yang ditimbulkan juga beraneka ragam sesuai dengan banyaknya jenis barang yang tergolong dalam barang hasil pertanian. Dampak yang timbul atas putusan MA Nomor 70 Tahun 2013 juga relatif tidak sama antara satu jenis barang dengan jenis barang lainnya yang tergolong dalam barang hasil pertanian. Karena proses bisnis yang berlaku antara satu jenis barang dan jenis barang lainnya berbeda-beda. Selain itu juga ada faktor lain seperti kebijakan pemerintah yang dapat mempengaruhi dampak yang ditimbulkan atas keluarnya putusan MA Nomor 70 Tahun 2013. Untuk barang hasil pertanian berupa hasil pertanian tebu, faktor yang paling berpengaruh terhadap putusan MA Nomor 70 Tahun 2013 adalah proses bisnis yang berlaku pada pertanian tebu dan kebijakan pemerintah yang berlaku pada barang pertanian hasil pertanian tebu.

Proses bisnis yang berlaku pada pertanian tebu adalah sistem lelang. Barang hasil pertanian yang telah dipanen oleh petani tebu perkebunan rakyat, diserahkan kepada pabrikan untuk diolah. Kemudian hasil olahan itu dibayarkan kepada petani tebu dengan sistem bagi hasil. Hasil olahan yang diterima oleh petani tebu kemudian sebagian dititipkan kembali kepada pabrikan yang mengolah untuk dijual dan sebagian dijual langsung oleh petani ke pasar. Sedangkan kebijakan pemerintah yang berpengaruh terhadap pertanian tebu adalah Harga Eceran Terendah dan Harga Eceran Tertinggi. Untuk kebijakan Harga Eceran Terendah yang diterapkan pemerintah dilaksanakan pada saat lelang untuk melindungi produsen atau petani. Selain itu pemerintah menerapkan kebijakan Harga Eceran Tertinggi untuk melindungi konsumen atas produk hasil olahan pertanian tebu. Kebijakan Harga Eceran Tertinggi ini yang ternyata berkontribusi terhadap dampak yang ditimbulkan putusan MA Nomor 70 Tahun 2013.

Saat barang hasil pertanian masih termasuk dalam BKP tertentu bersifat strategis yang dibebaskan dari pengenaan PPN, atas penyerahan produk hasil pertanian tebu PPN yang dikenai sebesar nol. Akan tetapi, ketika barang hasil pertanian dicabut dari BKP tertentu bersifat trategis yang dibebaskan dari pengenaan PPN sehingga menjadi terutang PPN. Dampak yang ditimbulkan, petani harus membebankan PPN sebagai komponen HPP gula. Sedangkan margin keuntungan tidak dapat diubah karena terkendala oleh Harga Eceran Tertinggi yang ditetapkan oleh pemerintah. Dalam hal ini ditetapkan oleh Kementerian Perindustrian dan Perdagangan.

\section{Saran}

Terbitnya putusan MA Nomor 70 Tahun 2013 merupakan sebagian kecil dari permasalahan yang ada karena ketidaksesuai antara aturan dengan aturan lainnya. Padahal, atas peraturan yang telah berlaku yang kemudian menjadi tidak berlaku akan menimbulkan dampak yang sangat luas. Oleh karena itu, sebaiknya pemerintah lebih dalam mengkaji suatu aturan sebelum menerbitkan dan memberlakukan sebuah aturan.

Konflik kepentingan yang timbul diantara para pengusaha yang tergabung dalam KADIN juga bisa dijadikan sebagai pertimbangan oleh pemerintah dalam menetapkan aturan. 
Dengan memahami motif sesungguhnya dibalik uji materiil yang diajukan KADIN ke MA, diharapkan pemerintah bisa lebih berhati-hati dalam membuat peraturan perundang-undangan dan bisa mengatasi konflik kepentingan yang mungkin merugikan masyarakat umum.

Solusi yang dapat diterapkan atas permasalahan tersebut adalah petani dapat membentuk koperasi untuk kemudian menjalankan mekanisme P4PM dalam menghitung jumlah PM. Selain dapat mengurangi beban PPN yang ditanggung petani tebu, hal ini juga bermanfaat untuk DJP dalam menghimpun data dan informasi perpajakan. Sehingga DJP dapat memperoleh potensi lain yakni terkait pengawasan dan potensi Pajak Penghasilan Orang Pribadi atau Badan.

Kedepannya pemerintah diharapkan lebih mempertimbangkan kepentingan masyarakat luas. Selain itu, pemerintah dapat melakukan mediasi langsung terhadap masyarakat atau golongan yang terkena dampak oleh suatu kebijakan. Sehingga pemerintah bisa memberikan solusi yang tepat dan sesuai dengan permasalahan dan keperluan setiap pihak yang terdampak.

\section{DAFTAR PUSTAKA}

Arkhan, R. F., \& Rodhiyawan, W. W. (2021). Pengenaan Pajak Pertambahan Nilai Terhadap Jasa Penyelenggaraan Seminar. Educoretax, 1(2), 143-153. Diambil dari https://jurnalku.org/index.php/educoretax/article/view/15

Azizah, W. N., \& Wijaya, S. (2020). Overview Of Income Tax on More VAT Differences in Retail Used Motorcycle Retail. Dinasti International Journal of Economics, Finance \& Accounting, 1(1), 134-145.

Fauziyah, A. S. (2018). Implementasi ketentuan pajak pertambahan nilai atas kegiatan industri gula: studi pada pabrik gula PTPN X= Implementation of value added tax policy for sugar industry activities: study on sugar factory PTPN X.

Kementerian Pertanian. (2014). Outlook Komoditi Tebu. Jakarta: Pusat Data dan Sistem Informasi Pertanian Sekretariat Jenderal Kementerian Pertanian.

Nata, M. A. (2016). Penerapan Karakteristik Netralitas PPN Dikaitkan dengan fasilitas pembebasan PPN (Analisis Putusan MA No 70/P/HUM/2013). Surabaya: Universitas Pelita Harapan.

Utami, N. B. (2018). Kebijakan fasilitas pajak pertambahan nilai atas penyerahan tetes tebu (molasse) untuk mendukung perkembangan energi baru terbarukan= Policy on value added tax facility on sugarcane drops (molasses) submission to support renewable energy growth.

Wijaya, S., \& Nirvana, A. P. (2021). Pajak Pertambahan Nilai Perdagangan Melalui Sistem Elektronik (Studi Kasus PT Shopee Internasional Indonesia). Bilancia: Jurnal Ilmiah Akuntansi, 5(3), 245-256.

Wijaya, S., \& Sabina, D. I. A. (2021). Reformulasi Pengkreditan Pajak Masukan Pasca Omnibus Law. Jurnal Pajak Indonesia (Indonesian Tax Review), 5(1).

Wulandari, F. E. (2015). Perlakuan Akuntansi Pajak Pertambahan Nilai (PPN) Atas Jasa Giling Tebu di Pabrik Gula Toelangan (Doctoral dissertation, Universitas Islam Negeri Maulana Malik Ibrahim).

Permatasari, M. (2011). Kebijakan Price Floor dan Price Ceiling. (Online). (https://twentytwopm.wordpress.com/2011/11/04/kebijakan-price-floor-dan-priceceiling/, Diakses 30 Juni 2018)

Sae, Mr. (2017). Nasip Petani Tebu di Tengah Impor Gula. (Online). (https://www.kompasiana.com/sae/598f296afcf68168fd5680c2/nasip-petani-tebu-danharga-gula , Diakses 28 Desember 2017)

Sinaga, S. (2017). Mengurai Benang Kusut PPN atas Gula/Tebu. (Online). (http://forumpajak.org/benang-kusut-ppn-atas-gula-tebu/ , Diakses 28 Desember 2017) 
Journal of Law, Administration, and Social Science

Volume 1 No. 1, Juni 2021

Yudhistira, A. (2021). Pengenaan Pajak Pertambahan Nilai Pada Online Marketplace Tokopedia. Jurnalku, 1(1), 59-69. Diambil dari https://jurnalku.org/index.php/jurnalku/article/view/23

LAMPIRAN

Lampiran 1. Perkembangan Luas Panen Tebu di Indonesia Menurut Status Pengusahaan (1980-2016)

\begin{tabular}{|c|c|c|c|c|c|c|c|c|}
\hline \multirow[b]{2}{*}{ Tahun } & \multicolumn{8}{|c|}{ Luas Panen $(\mathrm{Ha})$} \\
\hline & PR & $\begin{array}{c}\text { Pertumb. } \\
\text { (\%) }\end{array}$ & PBN & $\begin{array}{c}\text { Pertumb. } \\
\text { (\%) }\end{array}$ & PBS & $\begin{array}{c}\text { Pertumb. } \\
\text { (\%) }\end{array}$ & INDONESIA & $\begin{array}{c}\text { Pertumb. } \\
\text { (\%) }\end{array}$ \\
\hline 1980 & 259.874 & 35,45 & 37.629 & $-70,16$ & 18.560 & $-27,31$ & 316.063 & $-8,01$ \\
\hline 1981 & 290.470 & 11,77 & 36.722 & $-2,41$ & 18.996 & 2,35 & 346.188 & 9,53 \\
\hline 1982 & 303.228 & 4,39 & 43.043 & 17,21 & 17.049 & $-10,25$ & 363.320 & 4,85 \\
\hline 1983 & 315.649 & 4.10 & 49.152 & 14,19 & 19.572 & 14,80 & 384.373 & 5,79 \\
\hline 1984 & 236.810 & -24.98 & 85.569 & 74,09 & 19.629 & 0,29 & 342.008 & $-11,02$ \\
\hline 1985 & 225.787 & $-4,65$ & 95.079 & 11,11 & 19.363 & $-1,36$ & 340.229 & $-0,52$ \\
\hline 1986 & 238.509 & 5.63 & 69.168 & -27.25 & 18.026 & $-6,90$ & 325.703 & $-4,27$ \\
\hline 1987 & 241.169 & 1,12 & 75.926 & 9,77 & 17.823 & $-1,13$ & 334.918 & 2,83 \\
\hline 1988 & 254.669 & 5.60 & 92.368 & 21,68 & 18.492 & 3,75 & 365.529 & 9,14 \\
\hline 1989 & 249.933 & $-1,86$ & 77.378 & $-16,23$ & 30.441 & 64,62 & 357.752 & $-2,13$ \\
\hline 1990 & 259.877 & 3.98 & 71.252 & $-7,92$ & 32.839 & 7,88 & 363.968 & 1,74 \\
\hline 1991 & 255.934 & -1.52 & 96.625 & 35,61 & 33.745 & 2,76 & 386.304 & 6,14 \\
\hline 1992 & 262.092 & 2,41 & 105.905 & 9,60 & 36.065 & 6,88 & 404.062 & 4,60 \\
\hline 1993 & 280.504 & 7.03 & 104.460 & $-1,36$ & 40.689 & 12,82 & 425.653 & 5,34 \\
\hline 1994 & 276.581 & $-1,40$ & 107.570 & 2,98 & 44.585 & 9,58 & 428.736 & 0,72 \\
\hline 1995 & 263.157 & $-4,85$ & 120.162 & 11,71 & 52.718 & 18,24 & 436.037 & 1,70 \\
\hline 1996 & 304.047 & 15,54 & 79.269 & $-34,03$ & 63.217 & 19,92 & 446.533 & 2,41 \\
\hline 1997 & 218.201 & -28.23 & 85.086 & 7,34 & 83.591 & 32,23 & 386.878 & $-13,36$ \\
\hline 1998 & 195.048 & $-10,61$ & 83.069 & $-2,37$ & 98.972 & 18,40 & 377.089 & $-2,53$ \\
\hline 1999 & 176.733 & $-9,39$ & 82.106 & $-1,16$ & 83.372 & $-15,76$ & 342.211 & $-9,25$ \\
\hline 2000 & 171.279 & $-3,09$ & 64.133 & $-21,89$ & 105.248 & 26,24 & 340.660 & $-0,45$ \\
\hline 2001 & 178.887 & 4.44 & 87.687 & 36,73 & 77.867 & $-26,02$ & 344.441 & 1,11 \\
\hline 2002 & 196.509 & 9.85 & 79.975 & $-8,79$ & 74.238 & $-4,66$ & 350.722 & 1,82 \\
\hline 2003 & 172.015 & $-12,46$ & 87.251 & 9,10 & 76.459 & 2,99 & 335.725 & $-4,28$ \\
\hline 2004 & 184.283 & 7,13 & 78.205 & $-10,37$ & 82.305 & 7,65 & 344.793 & 2,70 \\
\hline 2005 & 211.479 & 14.78 & 80.383 & 2,78 & 89.924 & 9,26 & 381.786 & 10,73 \\
\hline 2006 & 213.876 & 1.13 & 87.227 & 8,51 & 95.338 & 6,02 & 396.441 & 3,84 \\
\hline 2007 & 249.487 & 16,65 & 81.655 & $-6,39$ & 96.657 & 1,38 & 427.799 & 7,91 \\
\hline 2008 & 252.783 & 1.32 & 82.222 & 0,69 & 101.500 & 5,01 & 436.505 & 2,04 \\
\hline 2009 & 243.219 & $-3,78$ & 74.185 & $-9,77$ & 105.549 & 3,99 & 422.953 & $-3,10$ \\
\hline 2010 & 261.665 & 7.58 & 68.141 & $-8,15$ & 102.909 & $-2,50$ & 432.715 & 2,31 \\
\hline 2011 & 268.326 & 2,55 & 72.603 & 6,55 & 106.202 & 3,20 & 447.131 & 3,33 \\
\hline 2012 & 265.233 & $-1,15$ & 77.690 & 7,01 & 106.225 & 0,02 & 449.148 & 0,45 \\
\hline 2013*) & 280.419 & 5.73 & 77.967 & 0,36 & 107.733 & 1,42 & 466.119 & 3,78 \\
\hline \multicolumn{9}{|c|}{ Rata-rata Laju Pertumbuhan (\$) } \\
\hline 1980-2013*) & & 1,77 & & 1,73 & & 5,46 & & 1,06 \\
\hline $1980-1997$ & & 1,64 & & 3,11 & & 8,29 & & 0,87 \\
\hline 1998-2013*) & & 1,92 & & 0,18 & & 2,29 & & 1,28 \\
\hline
\end{tabular}


Journal of Law, Administration, and Social Science

Volume 1 No. 1, Juni 2021

Lampiran 2. Perkembangan Produksi Gula di Indonesia Menurut Status Pengusahaan (1980-2016)

\begin{tabular}{|c|c|c|c|c|c|c|c|c|}
\hline \multirow[b]{2}{*}{ Tahun } & \multicolumn{8}{|c|}{ Produksi (Ton) } \\
\hline & PR & $\begin{array}{c}\text { Pertumb. } \\
\text { (\%) }\end{array}$ & PBN & $\begin{array}{c}\text { Pertumb. } \\
\text { (\%) }\end{array}$ & PBS & $\begin{array}{c}\text { Pertumb. } \\
\text { (\%) }\end{array}$ & INDONESIA & $\begin{array}{c}\text { Pertumb. } \\
\text { (\%) }\end{array}$ \\
\hline 1980 & 893.120 & 21,37 & 273.355 & $-26,11$ & 93.475 & 16,02 & 1.259 .950 & 6,20 \\
\hline 1981 & 913.677 & 2,30 & 200.436 & $-26,68$ & 116.007 & 24,10 & 1.230 .120 & $-2,37$ \\
\hline 1982 & 1.373 .009 & 50,27 & 182.041 & $-9,18$ & 71.752 & $-38,15$ & 1.626 .802 & 32,25 \\
\hline 1983 & 1.240 .500 & $-8,65$ & 290.597 & 59,63 & 88.441 & 23,26 & 1.619 .538 & $-0,45$ \\
\hline 1984 & 1.397 .350 & 12,64 & 329.713 & 13,46 & 83.310 & $-5,80$ & 1.810 .373 & 11,78 \\
\hline 1985 & 1.450 .184 & 3,78 & 343.035 & 4,04 & 105.590 & 26,74 & 1.898 .809 & 4,88 \\
\hline 1986 & 1.567 .552 & 8,09 & 346.130 & 0,90 & 100.892 & $-4,45$ & 2.014 .574 & 6,10 \\
\hline 1987 & 1.743 .677 & 11,24 & 322.758 & $-6,75$ & 109.439 & 8,47 & 2.175 .874 & 8,01 \\
\hline 1988 & 1.575 .083 & $-9,67$ & 339.541 & 5,20 & 89.427 & $-18,29$ & 2.004 .051 & $-7,90$ \\
\hline 1989 & 1.621 .468 & 2,94 & 305.847 & $-9,92$ & 181.033 & 102,44 & 2.108 .348 & 5,20 \\
\hline 1990 & 1.609 .041 & $-0,77$ & 306.263 & 0,14 & 204.281 & 12,84 & 2.119 .585 & 0,53 \\
\hline 1991 & 1.612 .240 & 0,20 & 450.561 & 47,12 & 189.866 & $-7,06$ & 2.252 .667 & 6,28 \\
\hline 1902 & 1.652 .685 & 2,51 & 475.804 & 5,60 & 177.995 & $-6,25$ & 2.306 .484 & 2,39 \\
\hline 1993 & 1.684 .614 & 1,83 & 393.720 & $-17,25$ & 251.477 & 41,28 & 2.329.811 & 1,01 \\
\hline 1904 & 1.673 .246 & $-0,67$ & 509.047 & 29,29 & 271.588 & 8,00 & 2.453 .881 & 5,33 \\
\hline 1995 & 1.350 .476 & $-19,29$ & 422.300 & $-17,04$ & 286.800 & 5,60 & 2.059 .576 & $-16,07$ \\
\hline 1996 & 1.512 .131 & 11,97 & 316.660 & $-25,02$ & 265.404 & $-7,46$ & 2.094 .195 & 1,68 \\
\hline 1997 & 1.196 .409 & $-20,88$ & 365.313 & 15,30 & 630.264 & 137,47 & 2.191.986 & 4,67 \\
\hline 1998 & 759.094 & $-36,55$ & 305.332 & $-16,42$ & 423.843 & $-32,75$ & 1.488 .269 & $-32,10$ \\
\hline 1999 & 738.893 & $-2,68$ & 284.782 & $-6,73$ & 470.258 & 10,95 & 1.493 .933 & 0,38 \\
\hline 2000 & 790.573 & 6,99 & 234.288 & $-17,73$ & 665.143 & 41,44 & 1.690 .004 & 13,12 \\
\hline 2001 & 813.538 & 2,90 & 310.949 & 32,72 & 600.980 & $-9,65$ & 1.725 .467 & 2,10 \\
\hline 2002 & 967.160 & 18,88 & 297.685 & $-4,27$ & 490.509 & $-18,38$ & 1.755 .354 & 1,73 \\
\hline 2003 & 839.028 & $-13,25$ & 370.476 & 24,45 & 422.414 & $-13,88$ & 1.631.918 & $-7,03$ \\
\hline 2004 & 1.028 .681 & 22,60 & 383.892 & 3,62 & 639.071 & 51,29 & 2.051 .644 & 25,72 \\
\hline 2005 & 1.193 .653 & 16,04 & 423.421 & 10,30 & 624.668 & $-2,25$ & 2.241 .742 & 9,27 \\
\hline 2006 & 1.028 .681 & $-13,82$ & 383.892 & $-9,34$ & 639.071 & 2,31 & 2.051 .644 & $-8,48$ \\
\hline 2007 & 1.326 .937 & 28,90 & 356.504 & $-7,13$ & 833.933 & 30,49 & \begin{tabular}{|l|}
2.517 .374 \\
\end{tabular} & 22,70 \\
\hline 2008 & 1.382 .747 & 4.21 & 368.009 & 3.23 & 943.471 & 13,14 & 2.694 .227 & 7,03 \\
\hline 2009 & 1.326 .937 & $-4,04$ & 356.504 & $-3,13$ & 833.933 & $-11,01$ & 2.517 .374 & $-6,50$ \\
\hline 2010 & 1.295 .319 & $-2,38$ & 315.174 & $-11,59$ & 679.623 & $-18,50$ & \begin{tabular}{|l}
2.290 .116 \\
\end{tabular} & $-9,03$ \\
\hline 2011 & 1.366 .294 & 5.48 & 295.635 & $-6,20$ & 605.958 & $-10,84$ & 2.267 .887 & $-0,97$ \\
\hline 2012 & 1.543 .411 & 12,90 & 336.288 & 13,75 & 711.988 & 17,50 & 2.591 .687 & 14,28 \\
\hline $\left.2013^{*}\right)$ & 1.525 .197 & $-1,18$ & 331.073 & $-1,55$ & 694.722 & $-2,43$ & 2.550 .992 & $-1,57$ \\
\hline \multicolumn{9}{|c|}{ Rata-rata Laju Pertumbuhan (\%) } \\
\hline 1980-2013*) & & 3,34 & & 1,38 & & 10,75 & & 2,94 \\
\hline 1980-1997 & & 3,80 & & 2,38 & & 17,71 & & 3,86 \\
\hline 1998-2013*) & & 2,82 & & 0,25 & & 2,93 & & 1,91 \\
\hline
\end{tabular}


Journal of Law, Administration, and Social Science

Volume 1 No. 1, Juni 2021

Lampiran 3. Perkembangan Produktivitas Gula di Indonesia Menurut Status Pengusahaan (1980-2016)

\begin{tabular}{|c|c|c|c|c|c|c|c|c|}
\hline \multirow[b]{2}{*}{ Tahun } & \multicolumn{8}{|c|}{ Produktivitas (Ton/Ha) } \\
\hline & PR & $\begin{array}{l}\text { Pertumb. } \\
\text { (\%) }\end{array}$ & PBN & \begin{tabular}{|c|} 
Pertumb. \\
(\%)
\end{tabular} & PBS & $\begin{array}{c}\text { Pertumb. } \\
\text { (\%) }\end{array}$ & INDONESIA & $\begin{array}{c}\text { Pertumb. } \\
\text { (\%) }\end{array}$ \\
\hline 1980 & 3,44 & $-10,40$ & 7,26 & 147,64 & 5,04 & 59,61 & 3,99 & 15,42 \\
\hline 1981 & 3,15 & $-8,47$ & 5,46 & $-24,86$ & 6,11 & 21,26 & 3,55 & $-10,88$ \\
\hline 1982 & 4,53 & 43,85 & 4,23 & $-22,52$ & 4,21 & $-31,00$ & 4,48 & 26,01 \\
\hline 1983 & 3,93 & $-13,21$ & 5,91 & 39,79 & 4,52 & 7,37 & 4,21 & $-5,90$ \\
\hline 1984 & 5,90 & 50,15 & 3,85 & $-34,83$ & 4,24 & $-6,08$ & 5,29 & 25,63 \\
\hline 1985 & 6,42 & 8,85 & 3,61 & $-6,37$ & 5,45 & 28,48 & 5,58 & 5,43 \\
\hline 1986 & 6,57 & 2,33 & 5,00 & 38,70 & 5,60 & 2,84 & 6,19 & 10,83 \\
\hline 1987 & 7,23 & 10,01 & 4,25 & $-15,05$ & 6,14 & 9,71 & 6,50 & 5,03 \\
\hline 1988 & 6,18 & $-14,48$ & 3,68 & $-13,53$ & 4,84 & $-21,24$ & 5,48 & $-15,61$ \\
\hline 1989 & 6,49 & 4,80 & 3,95 & 7,53 & 5,95 & 22,87 & 5,89 & 7,48 \\
\hline 1990 & 6,19 & $-4,56$ & 4,30 & 8,75 & 6,22 & 4,60 & 5,82 & $-1,18$ \\
\hline 1891 & 6,30 & 1,74 & 4,66 & 8.48 & 5,63 & $-9,55$ & 5,83 & 0,13 \\
\hline 1902 & 6,31 & 0,10 & 4,49 & $-3,65$ & 4,94 & $-12,28$ & 5,71 & $-2,11$ \\
\hline 1993 & 6,01 & $-4,76$ & 3,77 & $-16,11$ & 6,18 & 25,23 & 5,47 & $-4,11$ \\
\hline 1994 & 6,05 & 0,73 & 4,73 & 25,55 & 6,09 & $-1,44$ & 5,72 & 4,57 \\
\hline 1985 & 5,13 & $-15,17$ & 3,51 & $-25,73$ & 5,44 & $-10,60$ & 4,72 & $-17,47$ \\
\hline 1996 & 4,97 & $-3,09$ & 3,99 & 13,67 & 4,20 & $-22,83$ & 4,69 & $-0,71$ \\
\hline 1997 & 5,48 & 10,25 & 4,29 & 7,48 & 7,54 & 79,50 & 5,67 & 20,81 \\
\hline 1908 & 3,89 & $-29,02$ & 3,68 & $-14,39$ & 4,28 & $-43,20$ & 3,95 & $-30,34$ \\
\hline 1909 & 4,18 & 7,43 & 3,47 & $-5,64$ & 5,64 & 31,71 & 4,37 & 10,61 \\
\hline 2000 & 4,62 & 10,40 & 3,65 & 5,32 & 6,32 & 12,04 & 4,96 & 13,64 \\
\hline 2001 & 4,55 & $-1,47$ & 3,55 & $-2,83$ & 7,72 & 22,13 & 5,01 & 0,98 \\
\hline 2002 & 4,92 & 8,22 & 3,72 & 4,97 & 6,61 & $-14,30$ & 5,00 & $-0,09$ \\
\hline 2003 & 4,88 & $-0,90$ & 4,25 & 14,07 & 5,52 & $-16,38$ & 4,86 & $-2,88$ \\
\hline 2004 & 5,58 & 14,44 & 4,91 & 15,61 & 7,76 & 40,54 & 5,95 & 22,41 \\
\hline 2005 & 5,64 & 1,11 & 5,27 & 7.31 & 6,95 & $-10,54$ & 5,87 & $-1,32$ \\
\hline 2006 & 4,81 & $-14,79$ & 4,40 & $-16,45$ & 6,70 & $-3,50$ & 5,18 & $-11,86$ \\
\hline 2007 & 5,12 & 6,41 & 4,81 & 9,10 & 7,72 & 15,20 & 5,70 & 10,19 \\
\hline 2008 & 5,36 & 4,71 & 4,83 & 0,43 & 8,24 & 6,71 & 6,00 & 5,28 \\
\hline 2000 & 5,12 & $-4,50$ & 4,81 & $-0,43$ & 7,72 & $-6,29$ & 5,70 & $-5,02$ \\
\hline 2010 & 4,69 & $-8,27$ & 4,63 & $-3,75$ & 6,17 & $-20,03$ & 5,04 & $-11,57$ \\
\hline 2011 & 4,81 & 2,40 & 4,21 & $-0,08$ & 5,46 & $-11,50$ & 4,87 & $-3,45$ \\
\hline 2012 & 5,82 & 21,05 & 4,33 & 2.83 & 6,70 & 22,78 & 5,77 & 18,51 \\
\hline $\left.2013^{*}\right)$ & 5,44 & $-6,53$ & 4,25 & $-1,90$ & 6,45 & $-3,70$ & 5,47 & $-5,15$ \\
\hline \multicolumn{9}{|c|}{ Rata-rata Laju Pertumbuhan (\%) } \\
\hline 1980-2013*) & & 2,05 & & 4,12 & & 4,93 & & 2,16 \\
\hline 1980-1997 & & 3,27 & & 7,50 & & 8,13 & & 3,52 \\
\hline 1998-2013*) & & 0,67 & & 0,33 & & 1,34 & & 0,62 \\
\hline
\end{tabular}

